\title{
Serbia's EU Future: Concerns and Perspectives
}

\author{
Branislav RADELJIĆ
}

\begin{abstract}
Since the early 1990s European involvement in the former-Yugoslav space has shifted from protecting and separating other republics and peoples from Serbia and the Serbs to supporting the new post-Milošević Serbian elites with the processes of democratization and Europeanization. This paper examines a number of challenges surrounding Serbia's European Union future. Accordingly, while noting that the Brussels administration has continuously confirmed its readiness to provide advice and assistance, the discussion suggests that both the stagnation and progress are likely to rest exclusively with the Serbs themselves. Keywords: European Union, Serbia, Kosovo, Russia.
\end{abstract}

The first major European intervention in Yugoslavia resulted in the collapse of the Yugoslav federation. The decision to recognize Slovenia and, more importantly, Croatia, meant that the war was then transferred to Bosnia and Herzegovina. Once the Milošević regime had realized that its intention of a Serbia-dominated Yugoslavia, serving the interests of the Serbs living outside the republic of Serbia, was not going to materialize, it pursued the policy of ethnic cleansing that resulted in the Srebrenica Genocide in July 1995. Still, the growing international criticism and isolation did not prevent the Serbian authorities from testing their power elsewhere: deeper ethnic antagonisms led to the outbreak of conflict in Kosovo in 1998, culminating in January 1999 when Serbian military forces committed a crime against humanity killing forty-five civilians in Račak. According to Joschka Fischer, the then German Foreign Minister, acting politely with Belgrade officials would lead only to more mass graves, so he stated that the use of force should be taken into consideration: "I am not a friend of using force, but sometimes it is a necessary means of last resort. So I am ready to use it if there is no other way. If people are being massacred, you cannot mutter about having no mandate. You must act". ${ }^{1}$ Following the termination of the NATO-led bombing campaign against Serbia in June 1999 (or the second major European intervention in the post-Yugoslav region), the West looked forward to the removal of Slobodan Milošević. In this paper, I examine a number of challenges capable of affecting Serbia's European Union (EU) future. Accordingly, while noting that the Brussels administration has continuously confirmed its readiness to provide advice and assistance, the discussion suggests that both the stagnation and progress are likely to rest exclusively with the Serbs themselves.

1 Fisher cited in Ivo H. Daalder and Michael E. O'Hanlon, Winning Ugly: NATO's War To Save Kosovo, Washington, DC: The Brookings Institution, 2000, p. 75. 
The overthrow of Milošević in October 2000 provided the Serbs with an opportunity to change their well-established image abroad as a vampire nation to that of one portraying them as regular human beings. Shortly after, the European Union decided to reward the newly elected anti-Milošević Democratic Opposition of Serbia by lifting its economic sanctions, securing reconstruction assistance, providing aid packages and signing trade agreements. The new Prime Minister Zoran Djindjić (whose main success was, in fact, the arrest and transmittal of Milošević to the International Criminal Tribunal for the former Yugoslavia (ICTY) in The Hague) kept saying that there was no time to waste. In his view, Kosovo was de facto independent and Serbia had to move on with the processes of democratization and Europeanization. However, on the other hand, the new President Vojislav Koštunica, who was also welcomed by the European officials as a symbol of new democratic orientation, did not fully agree with Djindjić's approach. For example, he rejected the urgency of the Kosovo status claiming that it was better to "wait for another five years, because the later this issue is addressed the better it will be for [the Serbs]". ${ }^{2}$ In addition, the delayed cooperation with the Hague tribunal was a confirmation of Koštunica's reluctance to break up with the Milošević era: on various occasions, he was accusing the tribunal of its undue interference and assault on the dignity of his state. ${ }^{3}$ As one survey covering the period 2001-2005 showed, Koštunica's rhetoric managed to influence the Serbian public to the extent that two thirds of the general public opposed any cooperation with the Hague tribunal. ${ }^{4}$

The assassination of Prime Minister Djindjić in 2003 represented an enormous loss for Serbia: the processes of democratization and Europeanization were immediately interrupted. Soon after the assassination and the replacement government headed by Zoran Živković, Koštunica became the new Prime Minister. As summarized elsewhere, "[t]he assassination stopped Serbian reforms in their tracks. It compromised further cooperation with the ICTY as the only element in the Serbian government inclined to cooperate was removed, and Koštunica went back to his entrenched position of noncompliance". ${ }^{5}$ The European officials were naïve enough to believe that he was ready to make a big step towards European integration, shifting from introverted post-communist conservatism to a modern,

2 UNMIK, "Djindjić Wants Status Resolved Now, Koštunica in Five Years", 2003 [http://www.unmikonline.org/press/2003/mon/jan/lmm200103.htm\#4], 12 October 2011.

3 Jacques Rupnik, "The Demise of Balkan Nationalisms? A Skeptical View", in Judy Batt (ed.), The Western Balkans: Moving on, Paris: Institute for Security Studies, 2004, p. 105.

4 Beogradski centar za ljudska prava, "Javno mnenje u Srbiji: Stavovi prema pravosudju za ratne zločine i Haškom tribunalu”, Beograd: Beogradski centar za ljudska prava, 2005.

5 Jelena Subotić, "Explaining Difficult States: The Problems of Europeanization in Serbia" in East European Politics and Societies, Vol. 24, No. 4, 2010, pp. 595-616: 601. 
democratic, and open society. Indeed, they continued to express their support for Serbia leading to the opening of negotiations for the Stabilization and Association Agreement with the EU in October 2005. However, given an obvious lack of cooperation with the Hague tribunal, the negotiations were suspended in May 2006 and reassumed only after the victory of the President Boris Tadić's Democratic Party, in the 2007 Serbian parliamentary elections.

The talks about the Kosovo status and various speculations about the regional implications of Kosovo's policy of independence accentuated the differences between the dominant political parties in Serbia. For example, Prime Minister Koštunica and his Democratic Party of Serbia insisted that "the existence of Kosovo and Metohija as part of Serbia and the existence of the Serbian people in Kosovo [were] the key objectives of Serbia's involvement in the political talks for the future status of that region" and any decision on Kosovo "should be made within Serbia, in the framework of the large autonomy of Kosovo and Metohija within Serbia". ${ }^{6}$ As one author observed, Koštunica was an ardent nationalist with a deep-seated suspicion of the West and a habit of postponing difficult decisions: he preferred being remembered as the patriot who succeeded Milošević than the president who gave away Kosovo. ${ }^{7}$

At the same time, President Boris Tadić and his Democratic Party reaffirmed that he would not sign any document on Kosovo's independence. The 2006 Serbian constitution presented the province of Kosovo as a constituent part of Serbia and he accordingly continued to insist on new rounds of negotiations, thinking that they could change the West's already established position. What such an approach has done so far is to manipulate both the Serbs living in Kosovo and the Serbs living elsewhere to believe that Kosovo will continue to belong to Serbia. The main difference between the former Prime Minister Djindjić and his successors has been that while Djindjić was capable of reading the EU's messages betweenthe-lines and thus understanding that the preservation of Kosovo within Serbian borders and Serbia's EU future could never go hand in hand, his successors have tried to convince the public that such an arrangement is actually possible. The majority of successors, often too much concerned with preserving their own political careers, tend to ignore the fact that it is not the European Union that needs Serbia, but rather the other way around. Accordingly, the compliance with the EU's policy of conditionality has often been assessed as insufficient. However, based on the number of official statements, it is not the Europeans who lack a clearer vision with regard to the future of Serbia, but the Serbs themselves. This is primarily due to the diametrically opposing views among domestic political

6 Regnum, "Vienna Talks: Albanians Don't Hurry to Recognize the Rights of Serbs in Kosovo", 2006 [http://www.regnum.ru/ English/623129.html], 15 October 2011.

7 Tom Hundley, "Wary Serbs Watch Deadlocked Talks on Kosovo's Independence”, Chicago Tribune, 10 June 2006, p. 1. 
elites. For example, Vojislav Šešelj's neo-fascist Serbian Radical Party and, to a lesser extent, Vojislav Koštunica's Democratic Party of Serbia and numerous former members of Milošević's Socialist Party of Serbia have often encouraged antiEuropean feelings. In their view, the process or Europeanization and eventual EU membership is not something Serbia should pursue. In order to justify such a standpoint, their statements are often inspired by European (and American, of course) involvement in the Yugoslav state crisis of the early 1990s and, more importantly, in the 1999 NATO bombing of Serbia. On the other hand, Tadić's Democratic Party and Tomislav Nikolić's Serbian Progressive Party have generally been proEuropean, although some of their members' statements and actions have occasionally undermined their apparent commitment to the process of Europeanization. Finally, the Liberal Democratic Party, led by Čedomir Jovanović, Prime Minister Djindjić'smain advisor, has continued to promote some of Djindjić's ideas and thus the necessary integration in the EU, but given its small size (like many other political parties in Serbia), it tends to remain rather marginal. Given that the elites do not share the same or rather similar standpoint with regard to the Serbia's European perspective, the process of Europeanization is further complicated. One study, while pointing out that in transitional systems "consensus about basic social, political, and economic priorities and values is often absent", sees public opinion surveys as a useful way to discover what society really thinks and what its main concerns are. ${ }^{8}$ For example, back in 2004, the Serbian Government Office for European Union Integration conducted a study in order to show how the Serbian public approached Europe and accordingly, the respondents were divided in four categories. These categories comprise of the Euro-enthusiasts, who say that Serbia must make every effort in order to join the EU, Euro-realists, who perceive the integration in the EU as a necessity, Euro-skeptics, who question the intentions of Europe and the West in general, and the Euro-phobes, who fear the dominance of Western Europe and thus strongly oppose integration. ${ }^{9}$ Based on the results, Eurorealists were the dominant category ( $35 \%$ of respondents) while Euro-phobes were the least popular (12\% of respondents). Later on, following the Kosovo's declaration of independence in 2008, there were many opinions saying that European policy towards the region is a double standard policy and "[i]f there had been a credible alternative to the EU, the majority of Serbian voters would have probably opposed Serbian EU accession". ${ }^{10}$ In fact, some more recent studies show

8 Richard P. Farkas, Democratization in the Balkans: Prescription for a Badly Scarred Body Politic, Boston, MA: Northeastern University Press, 2007, p. 40.

9 Serbian Government Office for EU Integration, "Evropska orijentacija gradjana Srbije", 2004 [http://seio.sr.gov.yu], 5 January 2013.

10 Marko Stojić, "The Changing Nature of Serbian Political Parties' Attitudes towards Serbian EU Membership", SEI Working Paper 122, Brighton: Sussex European Institute, 2011, pp. 1-53: 20 . 
that support to join the EU has continually decreased: for example, in December $2010,57 \%$ of respondents were in favor of Serbia's EU membership, whereas in December 2011, this number dropped to $51 \% .^{11}$

\section{From the Politics of Alternatives to the Politics of Opportunities}

According to one 2008 study correctly assessed, since the breakup of the Yugoslav federation, "Serbia has been invariably late: late in recognizing the spirit of change in 1989, late in reacting to Milošević's devastating policies, late in seeing the reality in Kosovo, late in accepting the cooperation with The Hague as a conditional sine qua non, late in defining the EU integration as the highest priority and hence late in conducting absolutely necessary reforms". ${ }^{12}$ Indeed, various indexes and indicators, such as the 2010 Democracy Index, the Global Competitiveness Index and the Worldwide Governance Indicators have demonstrated that Serbia has been late. The only significant progress can be associated with the electoral democracy and elections. Still, elections cannot consolidate democracy; they only serve to confirm democratic legitimacy. What is needed is a strong link between democracy (free and fair elections) and constitutional liberalism (rule of law and limited power) that would lead to the establishment of permanent institutions characterized by depoliticized public sector and independent courts. ${ }^{13}$ Here, although European Union involvement can provide assistance and apply its policy of conditionality, it is the Serbian leadership that decides on the level and speed of cooperation with both the EU and the Hague tribunal and, accordingly, the more they are ready to cooperate, the bigger the awards will be. While cooperation with the Hague tribunal has progressed satisfactorily, ${ }^{14}$ resulting in Serbia's EU candidacy in 2012 , there are various issues that still require great attention. However, by this point, the dominant political parties had not synchronized their standpoints with regard to Serbia's key priorities and thus continued with the already wellembedded discourse of potential alternatives. The reputation of the Democratic Party seriously deteriorated and the fact that some of its officials seemed to have established their individual agendas, not fully reflecting the party's general aims - an aspect which further underlines the relevance of an earlier notion about strategic and ideological motives behind any party behaviour - questioned the unity and survival of the party. For example, in December 2011, Serbia's president

11 Serbian Government Office for EU Integration, "Serbia's EU Integration Supported by 51\% of Citizens", 2012 [http://www.seio.gov.rs/news.101.html?newsid=1121], 5 January 2013.

12 Irena Ristić, “Serbia's EU Integration Process: The Momentum of 2008”, Panoeconomicus, Issue 1, 2009, pp. 111-125: 122.

13 Ilija Vujačić, "Deset godina političke tranzicije u Srbiji”, Analiza politike, Summer 2011, pp. 18-23: 22.

14 Here I primarily refer to the arrest and extradition of Radovan Karadžić in 2008, and Ratko Mladić and Goran Hadžić, in 2011. 
and leader of the Democratic Party Boris Tadic tried to reassure the public by saying that "the speculations are completely unrealistic and untrue, because there are no divisions in the party, and added there are different stances within the party, the same as in all other institutions, since it is constituted of different people". ${ }^{15}$ However, soon after the 2012 presidential elections in Serbia it became clear that the defeated Democratic Party was facing some serious internal challenges and that lack of immediate strategy as how to proceed could eventually result in a split of the party.

What seems to be even more relevant for the outcome of 2012 elections was that the voters were extremely disappointed with Serbia's economic performance, level of corruption across all sectors, poverty and unemployment rates etc. ${ }^{16}$ Taking all these issues into consideration, it is reasonable to argue that Tadić and his people simply failed to convince the public that they deserved to stay where they were. As one scholar summarized the trend: "The average voter did not perceive the politics of the Democratic Party as clearly pro-European and reformist, but only as one of several politics, which do not differ much in their fundamental premises. The politics of [the Democratic Party] is not defined as a clear alternative to the politics of Tomislav Nikolić, or even, until recently, Koštunica, but only as a variation of the same or similar politics ... The voters did not have the impression that by choosing Nikolić, they were choosing a truly different politics, but more of an alternative to the existing one. A part of the 'liberal intelligence' and certain public figures joined this political confusion about the true consequences of presidential elections. Justifiably unsatisfied with the current tempo of democratic change in Serbia, they continued to advocate the standpoint that 'any electoral change' is good, and did so with increasing aggressiveness". ${ }^{17}$

Following the election of president Nikolić, some EU officials noted that Serbia was "at a crossroads"; his victory "proved that the country's political landscape had become more complex and that the EU needs to be involved in an intensive dialogue with Serbian authorities and all political leaders from the very first moment". ${ }^{18}$ At home, while the panic surrounding government formation was going on, the newly elected president decided to pay his first visit abroad, to Russia. Although informal in official terms, this visit opened numerous questions about the politics of alternatives and whether the new Serbian leadership, contrary to the electoral campaign, was going to minimize its links with the West and move

15 Boris Tadić, "No Divisions in the Democratic Party", Tanjug, 2011 [http://www.tanjug.rs/ news/27241/tadic--no-divisions-in-democratic-party.htm], 10 January 2013.

16 Zoran Stojiljković, "Izborna odluka", in Zoran Stojiljković (ed.), Zašto glasam, kako glasam, ako uopšte glasam, Beograd: Friedrich Ebert Stiftung, 2012, pp. 19-32: 30.

17 Žarko Korać, “The Time of Cohabitation”, Peščanik, 2012 [http://pescanik.net/2012/05/thetime-of-cohabitation/], 10 January 2013.

18 Miroslav Lajčák, "Serbia Faces Historic Turning Point", EUobserver, 2012 [http:// euobserver.com/opinion/116401], 18 January 2013. 
more towards the East. As reported, in Moscow, Russian president Putin started his welcome note by wishing Nikolić "to implement everything that was stated in [his] election program and to fulfill the Serbian people's expectations", that economic cooperation between the two "increased by almost $50 \%$ in the past year" and that Russians "see Serbs as [their] spiritual brothers". ${ }^{19}$ Based on Nikolić's response to Putin - that "Serbia is moving towards joining the EU" and that it will be built "in accordance with the rules of the EU", ${ }^{20}$ the informal talks in Moscow should not be interpreted as Serbian ambition to find an alternative and potentially give Russia priority over the EU.

Given the worrying economic situation at home, the newly established Serbian leadership has to explore opportunities that will eventually improve the living standard of the citizens of Serbia. While during the Cold War, the former Yugoslavia tried to preserve its economic relevance by deepening cooperation with the West, the impoverished post-Yugoslav Serbia is ready to receive investments from any geopolitical direction, even if sometimes this will not be possible due to the fluctuations in global economy. As Russia's deputy prime minister Dmitry Rogozin stated during his visit to Serbia, "[t]he difference between the EU's and Russia's approach is that Russia has the desire and money to invest in Serbia" and also underlined, something that is of crucial importance to pro-European forces, that "[t]here is no conflict of interest between Serbia's EU membership and friendship with Russia". ${ }^{21}$ For example, the South Stream project is seen as a big step forward: by having the pipeline passing through its territory, Serbia will get cheaper gas and Russia will secure access to a bigger European market and confirm its relevance in European Union affairs as the $21^{\text {st }}$ century is very much the century of energy politics. Additionally, a strong Serbian-Russian economic partnership could also lead to a strong political partnership, an upgrade that is surely facilitated by Nikolić's clear announcement in Moscow that "Serbia will never become a member of NATO". ${ }^{22}$

\section{Conclusion}

This paper has outlined some of the dominant issues affecting the overall progress of post-Milošević Serbia. Accordingly, the Kosovo question continues to represent a serious matter of concern. Although the Brussels administration has never said that it expects Serbia to give up its southern province in order to fully accede to the EU, it has become difficult to believe that this will not be the case. When discussing

19 Kremlin, "Meeting with Serbian President-Elect Tomislav Nikolić", 2012 [http://eng. kremlin.ru/transcripts/3914], 18 January 2013.

20 Ibid.

21 Tanjug, "Rogozin: Russia is with Serbia", 2012 [http://www.tanjug.rs/news/67723/rogozin-russia-is-with-serbia.htm], 18 January 2013.

22 Russia Today, "Serbia Says "nyet" to NATO Membership", 2012 [http://rt.com/politics/ serbia-russia-nato-eu-crisis-377/], 20 January 2013. 
Kosovo as a Serbian problem, it is important to note that the Belgrade authorities have supported the Kosovo Serbs to remain in Kosovo. However, one of the most alarming issues regards the presence of Serbian enclaves in the province that are still fully politically and economically integrated with Serbia. Thus, the question is how are these enclaves going to integrate within independent Kosovo and, secondly, who is responsible for this process? Still, when thinking about Kosovo as a European problem, there are also various aspects that deserve attention. For example, given the numerous criteria that any country seeking membership in the European Union must satisfy, ${ }^{23}$ it is objective to say that Kosovo is likely to face numerous obstacles. Even when negotiating the Kosovo status, the Brussels officials insisted on the policy of "standards before status", inaugurated by the third UN Mission in Kosovo chief, Michael Steiner of Germany, but once it had become obvious that standards were not going to be fulfilled any time soon, the policy was abandoned. In addition, Kosovo is formally recognized by 23 out of 28 Member States of the European Union. The remaining five states (Cyprus, Greece, Romania, Slovakia and Spain) do not intend to recognize Kosovo's independence, as their decision to do so could generate various problems at home.

It is worth mentioning that the most recent surveys conducted in Serbia have noted continuous drop of support for the country's EU membership, with data showing that " 59 percent of citizens do not believe that Serbia would access the EU in 10 or 15 years because nobody can guarantee this". ${ }^{24}$ Given that the volume of contacts, prospects for cooperation and promises exchanged between Serbia and Russia has remarkably increased since $2007,,^{25}$ it would be interesting to see if the continuous lack of pro-EU support has also to do with the intensified Russia-Serbia relations - a link that various members of the Serbian non-governmental sector see as groundless: "It is obvious that without Russia's involvement and without its support in certain informal centres, Serbia would not be in the situation in which it unfortunately finds itself today. Our elite naively believes that it is in Russia's interest to support

23 Any country seeking membership in the European Union must conform to the conditions set out by Article 49 and the principles laid down in Article 6 (1) of the Treaty on the EU. The relevant criteria were established by the Copenhagen European Council in 1993 and strengthened by the Madrid European Council in 1995. To join the EU, a new Member State must meet three criteria: political (implying stability of institutions guaranteeing democracy, the rule of law, human rights and respect for and protection of minorities), economic (implying existence of a functioning market economy and the capacity to cope with competitive pressure and market forces within the Union) and must accept the Community acquis (implying ability to take on the obligations of membership, including adherence to the aims of political, economic and monetary union; for the European Council to decide to open negotiations, the political criterion must be satisfied).

24 B92, "Support for the EU Plummets among Serbians", 2013 [http:/www.b92.net/eng/news/ politics-article.php?yyyy=2013\&mm=01\&dd=29\&nav_id=84394], 30 January 2013.

25 Žarko N. Petrović (ed.), Russia Serbia Relations at the Beginning of XXI Century, Belgrade: ISAC Fund, 2010. 
Serbia. It is a naïve way of looking at the world, bound up with the provincialism that imbues our perception of the world and what is happening around us". ${ }^{26}$

However, with the election of a new government in 2012, Serbia was once again exposed to the question of alternatives and speculations, but this time the situation seemed rather different, as the new government presented itself as fully aware both of the aforementioned uncertainties and Serbia's opportunities. With this in mind, there has not been much space left for the politics of alternatives. In contrast to the Djindjić government, which believed that Serbia did not have an alternative to the European Union, and the leadership that took over, which often struggled to confirm the previous view, leaving an impression that Serbia might have an alternative elsewhere, the Progressivists-dominated leadership is focused on potential benefits, regardless of the provider. Surely, the Russian federation is not an alternative at the moment, economically or ideologically. Economically, the EU is Serbia's biggest trade partner, accounting for 56 percent of domestic exports. ${ }^{27}$ Ideologically, although Titoist Yugoslavia was often proud of its similarity to the Soviet Union, the present-day Serbs are trying to be closer to the EU and the West in general rather than the Russians. In addition, Russia's decision not to recognize Kosovo's independence should not be necessarily associated with ideological proximity; it could also be perceived as its own ambition to be more relevant in EU and international politics. The desire for eventual membership in the European Union is a common denominator for all Western Balkan countries. It is an incentive to develop modern and effective legislation, and to reform and stabilize the political and economic environment. For example, in Serbia, corruption is recognized to be the biggest problem wherein political leaders are expected to solve them. The police and bureaucracy, while being the two elements with the greatest impact on our lives, "are the two most prevalent environments for 'corruption' simply because they are best positioned to leverage their power over common people". ${ }^{28}$ In contrast to the previous leadership, the 2012 elected government decided to tackle this problem first.

Still, without the full support from Brussels, there is little hope that Serbia and the Western Balkans will be able to shake off their existing reputation. The worstcase scenario would be to allow an increase in the already evident disproportion between the region and its neighbors who are further advanced in EU integration process. The (Western) Balkan question is a European question. So far, luckily, the Europeans have always confirmed their interest and willingness to assist the region, even if their involvement often entails taking responsibilities for acts in the past and calls for compromise.

26 Sonja Biserko, "Serbia'a Alternatives", Radio Slobodna Evropa, 12 December 2011.

27 Tanjug, "Delević: EU is Serbia’s Main Trade Partner", 2012 [http://www.tanjug.rs/ news/36110/delevic--eu-is-serbias-main-trade-partner.htm], 18 January 2013.

28 Richard P. Farkas, Democratization in the Balkans: Prescription for a Badly Scarred Body Politic, Boston, MA: Northeastern University Press., 2007, pp. 80-81. 